\title{
UNIVERSITYOF
}

FORWARD

THINKING

WESTMINSTER用

WestminsterResearch

http://www.westminster.ac.uk/westminsterresearch

Home bias persistence in foreign direct investments

Levis Mario, Muradoglu Yaz Gulnur and Vasileva Kristina

This is an Accepted Manuscript of an article published by Taylor \& Francis in The European Journal of Finance, 27 March 2015, available online:

http://www.tandfonline.com/https://dx.doi.org/10.1080/1351847X.2015.1019640.

The WestminsterResearch online digital archive at the University of Westminster aims to make the research output of the University available to a wider audience. Copyright and Moral Rights remain with the authors and/or copyright owners.

Whilst further distribution of specific materials from within this archive is forbidden, you may freely distribute the URL of WestminsterResearch: ((http://westminsterresearch.wmin.ac.uk/).

In case of abuse or copyright appearing without permission e-mail repository@westminster.ac.uk 


\title{
HOME BIAS PERSISTENCE IN FOREIGN DIRECT INVESTMENTS ${ }^{1}$
}

\author{
Mario Levis ${ }^{2}$ \\ Yaz Gülnur Muradoğlu ${ }^{3}$ \\ Kristina Vasileva ${ }^{4}$
}

\begin{abstract}
The purpose of this paper is to analyse the issues related to home bias and foreign direct investments. We study the role of physical, cultural, and institutional distances from home on foreign direct investment decisions taken by corporations to assess whether the globalization of the past two decades has reduced their influence. Using the "home bias" framework from the finance literature and the gravity model from the economics literature, we utilize a large sample of both developed and emerging markets, using foreign direct investment (FDI) flows of 6,263 unique bilateral country pairs over a 30 -year period. We find strong empirical evidence of persistent home bias in FDI outflows, and we show that not only physical distance but also cultural and institutional similarities between host and source countries remain a decisive factor in foreign corporate investment decisions. We also show that such home bias is persistent over time and is observed around the world.
\end{abstract}

Keywords: Foreign Direct Investment; Home Bias; Gravity Model; Panel Data;

JEL Classification: C33, F21, F23, G02

\footnotetext{
${ }^{1}$ We would like to thank Richard Fairchild, Natasha Todorovic, Kate Phylaktis, Saira Latif, Anna Faelten and participants of Research Days at Cass Business School, the Midwest Finance Association, Asian Finance Association, Behavioural Finance Working Group Conference for helpful comments and constructive criticisms on this and earlier versions of the paper.

${ }^{2}$ Cass Business School, Bunhill Row, EC1 8TZ, London, UK. Tel: +44(0)2070400124;

${ }^{3}$ Queen Mary University, Francis Bancroft Building, Mile End Road, London, E14NS, UK; Tel: +44 (0)2078826929106;

${ }^{4}$ Westminster Business School, 35 Marylebone Road, London, NW15LS, UK; Tel: +44(0)20 35066771; corresponding author: K.Vasileva@westminster.ac.uk
} 


\title{
HOME BIAS PERSISTENCE IN FOREIGN DIRECT INVESTMENTS
}

\begin{abstract}
The purpose of this paper is to analyse the issues related to home bias and foreign direct investments. We study the role of physical, cultural, and institutional distances from home on foreign direct investment decisions taken by corporations to assess whether the globalization of the past two decades has reduced their influence. Using the "home bias" framework from the finance literature and the gravity model from the economics literature, we utilize a large sample of both developed and emerging markets, using foreign direct investment (FDI) flows of 6,263 unique bilateral country pairs over a 30 -year period. We find strong empirical evidence of persistent home bias in FDI outflows, and we show that not only physical distance but also cultural and institutional similarities between host and source countries remain a decisive factor in foreign corporate investment decisions. We also show that such home bias is persistent over time and is observed around the world.
\end{abstract}

Keywords: Foreign Direct Investment; Home Bias; Gravity Model; Panel Data;

JEL Classification: C33, F21, F23, G02 


\section{HOME BIAS PERSISTENCE IN FOREIGN DIRECT INVESTMENTS}

\section{Introduction}

Home bias in finance was initially used to describe the fact that stock market investors hold only small amounts of foreign equity and do not benefit from international diversification. Home bias in the equity markets was first documented by French and Poterba (1991), and Tesar and Werner (1995). Later Coval and Moskowitz (1999) extended the definition of home bias by showing that home bias is not limited to underweighting of foreign assets in international portfolios, but also includes the preference for investing close to home as in the case of asset managers that exhibit a strong preference for locally headquartered firms. ${ }^{1}$ Home bias in international trade is documented by McCallum (1995) who showed that for the USA and Canada, inter-province trade is 20 times larger than international trade, and Wolf (2000) who showed home bias within the states in the USA.

In this paper, we study home bias in Foreign Direct Investments (FDI). Our approach is similar to Coval and Moskowitz (1999), but we investigate the relation between bilateral FDI flows and their closeness to home. Unlike the trade in goods and services involving transportation costs, there is no obvious reason why physical distance should have a negative effect on the international flow of direct investments. Although we use a set of economic cultural and institutional factors that explain FDI flows, we show that closeness to home remains significant. Thus, notwithstanding the rapid growth of FDI by Multinational Companies (MNC) across nations by around $470 \%$ over the past two decades that often leaves the impression that distances, physical, cultural or institutional, have shrunk, and the world has finally become a global village, our evidence suggests that home bias in FDI remains persistent. 
Home bias in equity investments can be due to investors having better access to information about local firms. According to van Nieuwerburgh and Veldkamp (2009), the argument of better information is a replacement of the assumption of capital immobility in international trade with the assumption of information immobility in equity investments. In international trade, home bias can be due to the presence of formal and informal trade barriers following national borders, including various items such as language and culture, but then home bias should not exist on the subnational level, as reported by Wolf (2000).

We use a framework whereby we take into account the determinants of FDI both from the perspective of managers making the FDI decision and the perspective of the macroeconomic determinants of FDI. We use the gravity model to estimate the FDI flows between the countries empirically. In addition to the physical distance between the sending and receiving countries of FDI pairs, we incorporate various risk factors, including macroeconomic, legal, and political, as well as those that influence the information gathering and processing capacity of the managers who invest and conduct a number of robustness tests. In an era of capital market liberalization, as observed by Bekaert (1995), Bekaert et al. (2005), and Levine (2001), we should not expect impeded capital flows or investments guided by forces other than those of economics and finance.

Unrestrained flow of direct investment is a measure of globalization, according to the OECD (2008). We show that home bias is persistent over time even during the recent periods with higher degrees of globalization. Physical distance from home as well as cultural and institutional distances play a role in foreign direct investment decisions taken by corporations, even when we control for known economic factors.

There is wide literature on the determinants of FDI which we rely on to build upon our work in three aspects: the determinants of FDI from the perspective of managers, from the perspective of macro-economic analysis of international capital flows, and those that have 
used the gravity model to explain FDI flows. Even though by many accounts the world has flattened, distance is still very much a factor for investors (Cumming and Dai, 2010). Nachum et al. (2008) argue that a country's location will still influence the corporate managers' destination choices. With this in mind, we keep physical distance from home as a determinant of FDI in our analysis and use a gravity model in our empirical work, first introduced for international trade by Tinbergen (1962) and used by others to establish a link between distance and trade flows (Anderson, 1979; Bergstrand, 1985; Anderson and Wincoop, 2003; Disdier and Head, 2008; Feenstra et al., 2001). The gravity model has also been used in other work on international flows, including venture capital investments (Cumming and Dai, 2010), mergers and acquisitions (Di Giovanni, 2005), and FDI flows (Kleinert and Toubal, 2010; Hattari and Rajan, 2009; Head and Ries, 2008; Bergstrand and Egger, 2007; Bloingen, 2005; Grosse and Trevino, 1996). Different methodologies have been used in estimating the gravity equation (Anderson and Wincoop, 2003; Egger, 2000; Santos Silva and Tenreyno, 2006). We employ the Poisson Pseudo Maximum Likelihood methodology described in Santos Silva and Tenreyno (2006) in estimating the gravity equation, and account for observations where the FDI flow is zero, without truncating the sample and possible various patterns of heteroscedasticity.

From the perspective of managers, the theory work on psychic distance (Johanson and Vahlne, 1977; Johanson and Wiedersheim-Paul, 1975) was introduced in the FDI literature in the late 1970s through a series of case studies. It describes the factors that would influence managers when thinking about expanding their businesses abroad. Psychic distance is defined as, "...factors preventing or disturbing the flows of information between firm and market. Examples of such factors are differences in language, culture, political systems, level of education, level of industrial development etc..." (Johanson and Wiedersheim-Paul, 1975, p. 308). A range of psychic distance stimuli have been used in large datasets as significant 
predictors of trade flows (Dow and Karunaratna, 2006). We also expect corporate managers to prefer investing in foreign destinations near home, not only in terms of physical distance, but also in terms of psychic distance. In FDI studies, cultural proximity is often also assumed through geographical distance or shared borders (Benito and Gripsurd, 1992; Green and Cunningham, 1975; Grosse and Trevino, 1996; Habib and Zurawicki, 2002; Di Giovanni, 2005; Sethi et al., 2003). We use both physical distance and shared borders in our empirical tests. In addition, we control for three aspects of culture important in FDI decisions but usually proxied by physical distance: language, historical ties and organizational culture which, in many instances, are also closely related to each other.

Speaking the language of the destination country has been found to be a significant variable in predicting the FDI flows. It might lower the degree of asymmetric information and give superior ability to international investors to identify good investment opportunities (West and Graham, 2004; Dow and Karunaratna, 2006). Similarly, historical ties are important determinants of cultural proximity and familiarity (Benito and Gripsurd, 1992). Countries that were part of a single country in the past or were in a colonial relationship have similar attitudes or values. Corporate investors would feel at home in their foreign direct investments if able to understand the spoken languages or if the countries had historical ties such as being a different part of the same country some time ago.

Culture and shared cultural mentality (Sethi et al., 2003; Dow and Karunaratna, 2006) maintain an important place in international trade and direct investment studies. Siegel et al. (2013) study the relationship between egalitarianism and cultural distance and find it to be a significant predictor of international flows. Kogut and Singh (1988) use a definition of organizational fit as the match between administrative practices, cultural practices and personal characteristics of the target and parent firms to create a Cultural Distance Index, a composite index using deviations along Hofstede's (1980) indices on four cultural 
dimensions: power distance, uncertainty avoidance, masculinity/femininity and individualism. The elements making up the dimensions are organizational and managerial in character.

Institutional distance is defined as the extent of similarity or dissimilarity between the regulatory, cognitive, and normative institutions of two countries (Xu and Shenkar, 2002). Institutional distance is linked to the establishment of legitimacy in the host country and the transfer of strategic operations and organization practices from the parent firm to the subsidiary abroad. Being a member of the same economic union or having similar legal systems play a significant role in the investment decisions. Such similarities breed familiarity bias (Brainard, 1997), making it easier for corporate managers to make international investments if the destination markets have a similar structure to the home market. The work on behavioural aspects of the theory of the firm developed by Cyert and March (1963), and internationalization developed by Aharoni (1966), are important from the perspective of macroeconomic analysis of international capital flows. FDI literature started to develop in the 1950s through several theories on the motives for FDI: monopolistic (Kindleberger, 1969), oligopolistic (Knickerbocker, 1973; Caves, 1974) and Dunning's (1980) eclectic or OLI (ownership, location, internalization) paradigm. Much FDI literature rests on a partial equilibrium firm level framework used as a base for further empirical work (Blonigen, 2005). These studies, then, typically examine some macroeconomic factors (Froot and Stein, 1991; Wheeler and Mody, 1992; Grosse and Trevino, 1996; Brainard, 1997; Aitken and Harrison, 1999). Market size has been found to be a very significant and robust positive determinant of FDI (Lim 2001; Blonigen, 2005; Barba Navaretti and Venables, 2004, p.33). FDI literature also features some form of measurement for country openness as the second major determinant of FDI flows (Agarwal et al., 1991). Countries that are more 'open' with increased trade flows or portfolio investments would be more likely to engage in FDI. The 
standard measure for trade openness of a country is through the ratio of the sum of exports plus imports over GDP (Chakrabarti, 2001). Many early studies focus on factors affecting FDI flows in a single industry or a single country (Sethi et al., 2003). We use both variables in our empirical model and conduct our tests in a large panel of FDI outflows from 34 countries to all of their recipient pairs, spanning a thirty-year period.

Increased globalization has sparked interest in the geographic component of firm investment choices (Alcàcer, 2006). Financial globalization is defined as global linkages through cross-border financial flows (Yeyati and Williams, 2011). This is especially significant and beneficial for emerging markets. The costs of doing business abroad have dropped significantly, compared to some twenty years ago. Making an international telephone call or travelling is no longer featured as a major expense to doing business at great distances. Therefore, the FDI destination country choices should not show a home bias.

By the very nature of its motivation, FDI promotes stable and long-lasting economic links between countries through direct access to the FDI receiver economies and production means (OECD, 2008). With a proper policy setting, it also provides the host countries with advanced technological and economic development and promotes further international trade through access to new markets. These activities not only assist the development of countries, but in general help integrate world capital markets and increase their overall efficiency and the allocation of world resources.

FDI flows are a natural and widely available indicator of globalization precisely because they measure the extent of international (cross-border) investments which are made with the objective of forming a long-lasting interest in a country different from that of the investors. Although the barriers to international investment have fallen sharply in the past decades (Stulz, 2005), financial liberalization has not yielded to unobstructed cross-country investing. If this is the case for the equity markets, it is a natural and intuitive assumption that 
this should be examined in the case of foreign direct investments, and we expect home bias in FDI to be persistent over time.

We conduct a number of robustness tests using control variables that can explain the choice of investing near home. Physical distance, used in the gravity equation, can be a proxy representing the effect of other variables on managers' investment destination choices. Our empirical design allows us to measure whether home bias measured in terms of physical distance remains significant even when we control for those factors. The home bias literature in finance has attempted to explain the observed home bias effects mostly as a consequence of asymmetric information and transaction costs (Portes and Ray, 2005; Ahearne et al., 2004). We include a number of variables to see whether those explanations are to reduce the observed home country bias for foreign direct investments.

Trust (Guiso et al., 2009), for example, towards the destination country creates a perception of a safe investment opportunity and reduced risks and, thus, entices FDI. The existence of bilateral tax treaties can reduce transaction costs directly and stimulate cross border deals. Informational asymmetries are important in FDI decisions, as investors might find it more difficult to gather information on more 'distant' investment possibilities. Studies show that more knowledgeable investors are also more prone to invest and diversify their assets abroad (Graham et al., 2009); however, they also find the observable bias effects remain present, especially for less sophisticated investors.

Studies include various measurements and proxies for asymmetric information and transaction costs. Knowledge of the target market can be increased in a number of ways, for example, through the ability of the manager to relate to the target market. Some studies consider the manager experience (Naseem and Wei, 2012); others consider the adoption of certain accounting standards (Kose et al., 2010). Most frequently, communication activity indicators as well as indicators of good country governance are used to indicate asymmetric 
information and costliness of doing business in the target market. Gordon and Bovenberg (1996), Portes and Rey (2005), and Di Giovanni (2005) use telephone usage as a proxy for information costs. We use the international telephone calls per capita for the FDI host country, as well as another similar indicator for the business information availability such as the availability of the Financial Times newspaper to proxy for the extent of informational asymmetries in the FDI receiving country for international investors.

Finally, country-specific governance is also an important factor for doing business in a particular location because it affects the availability of information in the FDI receiving country and makes investments in places of low country governance costly. Kaufmann et al. (2009) capture country specific factors of governance through accountability, political stability, government effectiveness, and regulatory quality, rule of law, and control of corruption. These indicators have been used in FDI literature (Bénassy-Quéré et al., 2007; Habib and Zurawicki, 2002) and are found to have a stimulating influence on FDI. Investors prefer locations where there is political stability and rule of law, where governments work effectively, and where regulatory quality and accountability are high, and corruption is under control. We believe those attributes of the business environment lower the cost of uncertainty in the investment process and, thus, increase foreign investments.

The paper is organized as follows: Section 2 outlines the gravity model and its econometric adaptation for the purposes of this study, while Section 3 describes the dataset used in this study; Section 4 presents the results, and Section 5 concludes.

\section{The Model}

We will test for home bias in FDI outflows using the gravity model. Its origins are in physics, in Newton's second law of gravity, and first introduced in economics by Tinbergen (1962). He developed the gravity model to explain international trade flows between bilateral country pairs, and it has since been frequently used due to its empirical success. The 
theoretical reasons for the gravity model have been called into question many times (Anderson, 1979; McCullum, 1995; Feenstra et al., 2001; Anderson and Wincoop, 2003; Disdier and Head, 2008). The gravity model has many variations, but it always includes two main parts, mass and distance. Beyond that, studies often control for different factors. It can be written as:

$$
F_{i, j}=G \frac{M_{i}^{\alpha} M_{j}^{\beta}}{D_{i j}^{\theta}}
$$

Where $F_{i j}$ is the force of attraction between the two objects $i$ and $j ; M_{i}$ and $M_{j}$ are the masses or sizes of the two objects; $D_{i j}$ is the distance between them, while $G$ is a constant that represents Earth's gravity force. From the equation, we can say the bigger their mass, the higher the force of attraction between them, and the more the distance between them, the less the force of attraction. This basic relation between an object's mass and its distance from other objects was taken as the basis for a natural relationship between two objects in economics by Tinbergen (1962). In economics, these two objects can be any number of things that have an interaction such as countries, cities, companies, and people, as well as in any number of relationships between them: general trade, imports, exports or direct investment.

Following this general premise of two main factors, mass and distance, we can say FDI flows are a function of the size of the respective economies in bilateral country pairs and the distance between them, as well as other contributing factors. Equation (1) can be transformed into a general log-linear function of the mass and distance (Anderson and Wincoop, 2003), as follows:

$$
\log \mathrm{F}_{\mathrm{i}, \mathrm{j}, \mathrm{t}}=\log \mathrm{M}_{\mathrm{i}, \mathrm{t}}+\log \mathrm{M}_{\mathrm{j}, \mathrm{t}}-\log \mathrm{D}_{\mathrm{i}, \mathrm{j}}+\mathrm{u}_{\mathrm{i}, \mathrm{j}, \mathrm{t}}
$$

Where $F_{i, j, t}$ are FDI flows from country $i$ towards country $j$ at time $t ; M_{i, t}$ and $M_{j, t}$ are country's $i$ and j's GDP at time t, respectively; $D_{i j}$ is the distance between the two countries 
that have an FDI relationship; $\mathrm{u}_{\mathrm{i}, \mathrm{j}, \mathrm{t}}$ stands for the error term. We are interested to see whether the physical distance between the FDI partners or being near home geographically, either by being located in the same continent or by sharing a border, increases FDI flows. In addition to this physical proximity, we use economic determinants of FDI, and non-geographic distances are represented through a group of cultural or institutional proximity variables. These variables capture any similarities that may exist between countries which may contribute to an observed home bias, similar to the one observed for international trade flows (Wolf, 2000). We give details of the additional variables we use below.

When estimating the gravity model, different studies have used a variety of methodologies (Anderson and Wincoop, 2003; Egger, 2000; Santos Silva and Tenreyno, 2006, 2011). We apply the Poisson Pseudo Maximum Likelihood (PPML) methodology developed by Santos Silva and Tenreyro (2006), which is superior to log linearized models using OLS. This method enables us to address the problems usually encountered in OLS estimations of the gravity model. The first is the use of income variables (GDP) in explaining FDI where it is not possible to argue that these variables are independent and that an increase in FDI can also lead to an increase in GDP and, thus, the possibility of an endogeneity bias in the estimated coefficients. We use IV estimates (results not reported here) to address this problem, and our conclusions do not change. The second problem arises due to the $\log$ linearization of the empirical model in the presence of heteroscedasticity which leads to inconsistent estimates of the elasticity coefficients. The PPML estimation technique we employ is robust to different patterns of heteroscedasticity. The third problem is due to the nature of the dataset we use; there are no FDI outflows in some years in certain country pairs. One possible solution is to truncate the sample to exclude these observations which creates a source of bias in the parameter estimates of the log-linear model. PPML estimations also help 
resolve this "zero-trade", in our case zero FDI problem, by enabling us to use the full sample, including the zero observations. We estimate the following model using $\mathrm{PPML}^{2}$ :

$$
\mathrm{FDI}_{\mathrm{i}, \mathrm{j}, \mathrm{t}} \text { (outflows) }=\exp \left[\beta_{0}+\beta_{1}\left(\gamma_{1}\right)+\beta_{2}\left(\gamma_{2}\right)+\beta_{3}\left(\gamma_{3}\right)+\beta_{4}\left(\gamma_{4}\right)+\beta_{5}\left(\gamma_{5}\right)+\varepsilon_{\mathrm{i}, \mathrm{j}, \mathrm{t}}\right]
$$

Where: FDI ${ }_{i, j, t}$ is the FDI outflows from country $i$ to $j$ at time $t ; \gamma_{1}$ is for the macroeconomic variables that denote the economic pull or strength of the country (the GDP and the country trade openness); $\gamma_{2}$ is for three geographical proximity variables (physical distance, shared border and same continent dummies); $\gamma_{3}$ is for institutional distance variables (same origin of the country's legal system and common membership to a political or economic union); $\gamma_{4}$ is for the cultural familiarity variables (shared language dummy, shared history and the cultural distance index); $\gamma_{5}$ stands for any one of the following variables: bilateral trust index, international phone minutes per capita for the receiving country, Financial Times circulation per capita for the receiving country, bilateral tax treaties for double tax avoidance, and any of the six world governance indicators, including voice and accountability, political stability, government effectiveness, regulatory quality, rule of law, and control for corruption; and $\varepsilon_{\mathrm{i}, \mathrm{j}, \mathrm{t}}$ stands for the error term. The variables used in this model are discussed in greater detail in Section 3. Equation (3) is estimated using the full panel dataset and additionally, over time. Given that our dataset is an unbalanced panel with variables that vary over time, there could be some unobserved heterogeneity.

Fixed effects are frequently used in studies using the gravity model for trade or FDI (Egger, 2000; Bergstrand and Egger, 2007) because of the possibility of cross country or time (business cycle) effects, especially when panel data are used. Bilateral pair (cross section) fixed effects are thus included in studies with a basic gravity model specification to eliminate any omitted variable bias associated with unobserved time-invariant, pair-specific heterogeneity (Bergstrand and Egger, 2007) not captured by bilateral dummy variables for different geographical, historical or political contexts (Egger, 2000). Our model focuses on 
examining distances between country pairs using time-invariant bilateral dummy variables when demonstrating home bias in FDI outflows. We apply time fixed effects; these coefficients are not reported in the results tables for brevity. The standard errors in all estimations are corrected using the Huber (1967) and White (1980) estimators.

\section{Data}

We investigate home bias in FDI flows in a bilateral country framework across a large number of countries using data from the OECD database. For our analysis, we consider all available non-negative FDI outflows for the 34 OECD member countries ${ }^{3}$ and their available partner countries, from 1981 to 2010; the data are in constant US million dollars. We define an observation as the FDI outflow from country $i$ to country $j$ at a given year $t$. We consider sovereign countries. The dataset is an unbalanced panel and includes a total of 66,465 observations for FDI outflows which groups into 6,263 unique bilateral country pairs (without their time series). Our sample is well diversified, and only $1,166(1.7 \%)$ observations (of the 66,465 FDI outflows) occur among the G7 member countries, and the remainder are spread out throughout the rest of the world. Table 1 presents descriptive statistics.

\section{[Insert Table 1here]}

Starting with the variables central to this study, we use three to measure the physical proximity between the countries and capture the effects of the distance from different perspectives. The geographic proximity (distance) measures the real distance between the two countries in the bilateral pair (in kilometres) and is obtained from the CEPII. ${ }^{4}$ The second proxy for distance is a dummy variable that shows if the two countries in the pair are located on the same continent. The shared border variable is a dummy variable that takes the value of one if the two countries in the bilateral country pair share a border. Although two of these 
variables are correlated, ${ }^{5}$ we keep all of them in our regressions because they offer a unique perspective on different aspects of physical distance.

The shared membership to an economic or political union is a dummy variable (constructed by the authors) which takes the value of one if both countries in the bilateral country pair are members of either one of the following international organizations or unions: the OECD, the European Union (EU), the Commonwealth of Nations, or North American Free Trade Association (NAFTA). The country membership in the individual organizations and unions is consolidated in a single dummy variable.

The same origin of the legal system is a dummy variable that takes the value of one if both countries in the bilateral country pair share the same type of legal system. Data on country origin of the legal system are from La Porta et al. (1998), with the legal systems of the world divided into 5 categories: British, French, German, Socialistic, and Scandinavian.

The shared official language or language spoken by a minority is a dummy variable that takes the value of one if the countries in the bilateral country pair have the same official language, or if there is a minority of at least $14 \%$ that speaks the official language of the other country. The data on this dummy variable were taken from the CEPII.

The shared history variable is a dummy variable that takes the value of one if there are certain shared historical events between the two countries in the bilateral country pair. It is a dummy variable comprised from five other dummy variables: dummy if the countries have had a common colonizer after 1945, have ever had a colonial link, have had a colonial relationship after 1945, are currently in a colonial relationship, or were/are the same country.

The cultural distance index is calculated, following Kogut and Singh (1988), and is based on the four cultural dimensions proposed by Hofstede (1980). The data on these dimensions are from Geert Hofstede. ${ }^{6}$ The four dimensions are: power distance index (the extent to which the less powerful members of organizations and institutions accept and 
expect that power is distributed equally); individualism (the degree to which individuals are integrated into groups); masculinity (the distribution of roles between genders); and uncertainty avoidance index (society's tolerance for uncertainty and ambiguity). The index is calculated using the following formula:

$$
\mathrm{CD}_{\mathrm{i}, \mathrm{j}}=\frac{\sum_{\mathrm{i}=1}^{4}\left\{\frac{\left(\mathrm{I}_{\mathrm{d}, \mathrm{i}}-\mathrm{I}_{\mathrm{d}, \mathrm{j}}\right)}{\mathrm{V}_{\mathrm{d}}}\right\}}{4}
$$

Where the $I_{d, i}$ and $I_{d, j}$ is the individual cultural dimension (d) for country $i$ and $j$, respectively, and $\mathrm{V}_{\mathrm{d}}$ is the variance of each of the cultural dimensions. We expect this variable to have a negative coefficient indicating that corporate managers prefer destinations with similar organizational cultures. The cultural dimensions range from 0-100, and we use the logarithm of the index for our analysis.

The fourth set of variables is macroeconomic. Data on the macroeconomic variables are from the World Bank. The gross domestic product of the FDI receiving and sending countries (GDPrec, GDPsend, respectively) measured as the FDI flows in constant (2005) \$US are used to show the economic magnitude of the two markets involved in an FDI relationship, one of the main attracting factors between two economic entities. We use a standard literature measure for a country's openness to trade as the sum of exports and imports over GDP for both the FDI outflows receiving and sending countries.

We adopt the bilateral trust index as used in Guiso et al. (2009). The index measures bilateral trust between citizens of two countries in a sample of 15 European countries. ${ }^{7}$ The data are a set of surveys conducted by Eurobarometer and sponsored by the European Commission (Guiso et al., 2009). We expect a greater degree of trust to have a positive influence on FDI flows.

Asymmetric information is quite difficult to measure directly; studies most commonly use telephone communication and media as a proxy for the amount of information available to and for investors. We add two variables for asymmetric information: the international 
telephone calls in the FDI receiving country measured in minutes, and divided by the country's population (per capita). These data on international telephone calls are obtained from the International Telecommunications Union $^{8}$ (this institution no longer collects or disseminates bilateral international telephone traffic as used in Portes and Ray (2005) and Di Giovanni (2005)). These data are available from 1995 to 2010. We have obtained all available data on annual newspaper circulation (from 1997-2010) from the Financial Times (it is used per capita). We constructed a dummy variable to denote 'one' if the two countries in the bilateral country pair have a signed bilateral treaty for double taxation avoidance. The variable is constructed by the authors from data available in UNCTAD's country profile database. $^{9}$

For corporate governance, we include six variables from the World Governance Indicators (WGI) ${ }^{10}$ available for all countries from 1996-2010. The six aggregate indicators (Kaufman et al., 2009) are as follows: Voice and Accountability captures perceptions of the extent to which a country's citizens are able to participate in selecting their government, as well as freedom of expression, freedom of association, and a free media; Political Stability and Absence of Violence captures perceptions of the likelihood the government will be destabilized or overthrown by unconstitutional or violent means, including politicallymotivated violence and terrorism; Government Effectiveness captures perceptions of the quality of public services, the quality of the civil service and the degree of its independence from political pressures, the quality of policy formulation and implementation, and the credibility of the government's commitment to such policies; Regulatory Quality captures perceptions of the ability of the government to formulate and implement sound policies and regulations that permit and promote private sector development; Rule of Law captures perceptions of the extent to which agents have confidence in and abide by the rules of society, and in particular the quality of contract enforcement, property rights, the police and 
the courts, as well as the likelihood of crime and violence; Control of Corruption captures perceptions of the extent to which public power is exercised for private gain, including both petty and grand forms of corruption, as well as "capture" of the state by elite and private interests. The data are available for the following years only: 1996, 1998, 2000 and 20022010. We expect all the variables to have a positive influence on FDI flows. In the estimations, we use these indexes one by one due to the high correlation between the individual governance indicators.

\section{Home Bias in FDI}

Table 2 reports the results for home bias in FDI outflows. The FDI sending country is an OECD member, and the FDI receiving country is the partner country anywhere in the world. We start by estimating the basic gravity model and then add the other variables one by one.

\section{[Insert table 2 here]}

In column (1), we report results for the basic economic relation between FDI outflows and economic mass and distance, as established by the gravity model. The coefficient estimate for the GDP of the FDI sending and receiving countries is positive and significant, indicating that FDI outflows increase the higher the wealth of the countries. As income in the FDI receiving country increases, FDI flows to that country increase. Consistent with previous literature (Bergstrand and Egger, 2007), the coefficient estimate for distance is negative and significant, suggesting that FDI outflows are larger in countries that are geographically closer. In column (2), we add the country openness to trade as an additional macroeconomic explanatory variable. The coefficient estimates for the trade openness of both the FDI sending and receiving countries are positive and significant. As expected, countries more prone and open to trade have higher FDI flows. In column (3), we add the dummy variable equal to one if the partner countries are in the same continent. The coefficient estimate for the same 
continent dummy is not significant. In column (4), we use the dummy variable that defines whether the FDI sending and receiving countries share a border. The coefficient estimate for the shared border dummy is not significant, and neither is the shared continent variable.

In columns (5) through to (9), we incorporate one by one different variables from the institutional and cultural proximity groups, as described previously in the data section. In column (5), we report results including the dummy variable that measures if the FDI partner countries share membership with the same economic or political organization. The coefficient estimate for the shared economic organization dummy is positive and significant. The economic structure and institutional quality in FDI sending and receiving countries is a major competitive advantage when investments are channelled towards countries in the same economic organization (Habib and Zurawicki, 2002). We observe that institutional similarity increases familiarity for investors.

Column (6) introduces a dummy variable that indicates whether the FDI sending and receiving countries have the same origin of legal system. The coefficient estimate for the same legal system dummy is positive, indicating that FDI outflows are higher towards countries having a similar legal system. Similarity of institutional environments is important in FDI decisions ( $\mathrm{Xu}$ and Shenkar, 2002). Other things being equal, it would be more advantageous to enter a foreign market with a familiar legal system. A dummy for shared history is added in column (7). The coefficient estimate for the shared history dummy is positive: firms invest more in countries with a common history such as having been part of the same country in the past or having had colonial ties (Guiso et al., 2009). The information advantage of expanding into an environment likely to be culturally and institutionally familiar to the environment from which the investor comes is highly beneficial. A shared history implicitly provides familiarity with business climates, and a common understanding of issues, 
and ways of resolving them. Historical similarities encourage the firms' expansion across borders.

Column (8) introduces a dummy variable that indicates whether the host and source countries have a shared official language, or a shared language spoken by a minority in either country. The coefficient estimate for the shared language dummy is positive. Language is a major component of cultural similarity (Dongmin et al., 2009; Guiso et al., 2009). Speaking the same language gives a competitive advantage to firms expanding abroad compared with their foreign competitors not speaking the same language. Ultimately, in column (9), we add the Cultural Distance (CD) Index. The CD index measures the similarity in organizational cultures in country pairs, as defined by Hofstede (1980), and is calculated following Kogut and Singh (1988). We can see that the index has a negative sign as expected, indicating the greater the distance in organizational cultures between the country pairs, the fewer the FDI outflows between them. Corporate managers prefer to work with managers having similar social and sociological values to those in their home country. The coefficient estimates for shared borders become insignificant when we include the cultural distance index in this estimation. Geographically distant countries on different continents not sharing a border such as Great Britain and New Zealand or Australia (very low CD index, between $0.12-0.16$ ) can have similar cultures. Once we account for cultural distance, we see that foreign investors also prefer destinations closer in cultural distance.

While economic factors such as country openness and GDP have been found to affect FDI flows, much remains unexplained in terms of how familiarity or psychic distance helps or hinders FDI decisions by corporate investors. FDI decisions are difficult to reverse, compared with portfolio investments in foreign destinations. The location decisions of foreign direct investors provide a good test of how familiarity breeds investment and the psychic distance measured via institutional and cultural distances matters. ${ }^{11}$ Using bilateral 
data on a wide set of countries, we show how a comprehensive set of factors of psychic distance and familiarity with the business environment are important in location decisions. Yet, physical distance between bilateral country pairs in an FDI relation remains always a significant factor; FDI investors prefer destinations near home.

\subsection{Home bias across time}

\section{[Insert table 3 here]}

In Table 3, we divide the sample into two sub-samples, from 1981-1995 and from 1996-2005, to examine any change in home bias over time. This divides the sample into two parts, broadly corresponding to the capital market liberalization period. It is important to account for the capital market liberalization in the world in the early to mid-90s (Bekaert, 1995; Bekaert et al., 2005) because it might impact FDI outflow patterns. One could argue the liberalization could diminish the importance of the home bias factors due to greater and easier capital mobility. The results of this analysis are shown in Table 3, and they support the general findings in Table 2. The physical distance remains significant through time and has not diminished as one would expect following years of globalizing trends. The other kinds of proximity, cultural and institutional, do not indicate that their influence has diminished through time. It is interesting to note that the cultural distance index is not significant in the first period, while it is significant in the second. This indicates that cultural similarities have increased their role in investment decisions. These results indicate that even though economic rationale dictates that with the diminishing presence of traditional barriers to trade and capital flows the distance between countries and nations would also diminish, we find that, if anything, it has increased over time.

\section{2. Possible explanations for the observed home bias}

The equity and international portfolio literature has looked for reasons and alternative explanations as to why we observe this home bias phenomenon. Similarly, the FDI studies 
have also controlled for country-specific political factors, or availability of information in the FDI host country (Green and Cunningham, 1975; Habib and Zurawicki, 2002). The home bias literature most frequently controls for asymmetric information and transaction costs (French and Poterba, 1991; Coval and Moskowitz, 1999) when looking to explain and control for alternative possibilities as to why there is home bias. Indeed, it makes intuitive sense to see whether countries invest in particular places because they simply cannot obtain information (for political or technological reasons), or whether it is simply too costly to invest where the managers cannot be trusted, where they would be subject to double taxation, or where there is poor country governance. To test for some of the proposed explanations for the existence of home bias, we add a few variables to the original model in equation (3). These results are presented in Table 4. Most of these variables significantly reduce the size of the sample due to their limited availability (in time series or country data availability).

[Insert table 4 here]

\subsubsection{Is home bias due to bilateral trust?}

We begin by adding the bilateral trust between the two countries in the country pair. The results of this regression are presented in Table 4(2). This variable is taken from Guiso et al. (2009) and, because this data consists of 15 European countries, we lose two of the other variables: shared continent, and economic and political union dummies. We can see that the bilateral trust index is both positive and significant. This confirms the findings in Guiso et al. (2009) in that bilateral trust plays a role in the cultural biases between countries and their subsequent economic relationship. All other variables follow the conclusions of the main regression in Table 2.

\subsubsection{Is home bias due to asymmetric information?}


To consider information availability as a possible explanation for home bias, we add two proxy variables: international telephone minutes per capita and Financial Times (FT) circulation per capita for the FDI outflows receiving country, reducing the sample to 15,419 and 12,725 observations, respectively. The results of these regressions are presented in Table 4(3) and 4(4). We can see that the international telephone call variable is not significant. This is inconsistent with previous findings (Coval and Moskowitz, 1999) in both home bias in equity markets and the FDI literature. The FT circulation per capita in the FDI host country is significant. This means that increased information availability in one country increases the investment appeal of that country. Despite the additional explanatory power of information availability, the home bias variables remain significant.

\subsubsection{Is home bias due to lack of bilateral tax treaties?}

The regression in Table 4(5) considers the influence of bilateral tax treaties for double taxation avoidance. Data are not available for five countries: Israel, Mexico, Korea, Slovenia, and Turkey. This variable is not statistically significant.

\subsubsection{Is home bias due to country governance?}

The results for the country governance factors in home bias in FDI outflows are presented in Table 5. Due to their limited availability across time, these variables reduce the sample to 12,399 observations. Results show that all the six governance indicators are significant and positive. This suggests that the individual country governance in the FDI outflows receiving country plays a role in the choice country. FDI investors prefer to invest in countries where there is better governance. The voice and accountability indicator is positive and significant, indicating that the greater the freedom of speech and expression of the citizens of one country, the greater the FDI flows to that country. The political stability indicator shows a positive and significant influence on FDI outflows. The greater the political stability and absence of violence, the higher the FDI flows. This is one of the most commonly 
used factors in the literature (Green and Cunningham, 1975; Grosse and Travino, 1996) to control for country risk and country governance when investing at a particular location, and our findings support the general findings in the literature. Government effectiveness relates to the perceptions of the quality of public services and independence from political pressures; the higher this quality and independence, the higher the FDI flows to that country. Regulatory quality shows the ability of the government to implement sound policies that promote the private sector; the greater this quality, the more FDI flows will be attracted. This variable is also positive and significant. The rule of law variable is positive and significant; the greater the rule of law (i.e. the extent to which the rules of the society are abided by), the greater the FDI flows to that country. Finally, the control of corruption is also both positive and significant, indicating investors prefer countries with greater control over corruption. Controlling for corruption is a common feature in FDI studies (Habib and Zurawicki, 2002), alongside political stability. It always demonstrates a significant effect on FDI flows.

The country governance quality in the FDI receiving country plays a role in the potential cost of investing in a particular country. Understandably, investors prefer to invest in countries that have better governance. This does not eliminate the other factors of home bias. All remain overwhelmingly significant and with the expected sign, showing that institutional and cultural familiarity still plays an important factor in the investment destination choices for FDI, in addition to the macroeconomic and governance factors.

\section{Conclusion}

We investigate the location choices for foreign direct investments worldwide using data on the FDI outflows of 6,263 unique bilateral country pairs for the 1981-2010 period. We find that home bias in FDI does not diminish over time, as one would expect from the increased globalization trends in the capital markets during the past two decades. We show that the physical distance from home is important for FDI location choices after we control 
for economic cultural and institutional factors. We also provide evidence that cultural and institutional similarities between host and source countries remain decisive factors across time, and different geographical areas, in corporate decisions on direct investments in foreign markets. We benefit from three strands of previous research in designing our empirical framework. We use the gravity model and show that all variables have expected signs, including distance GDP and openness of the economy. As physical distance is important in terms of costs of transportation in trade which is not the case for FDI investments, accordingly, we control for the determinants of FDI flows. We benefit from the two strands of literature on the determinants of FDI, both from the perspective of managers and from the perspective of macro-economic analysis of international capital flows, to control for various risk factors, including those that are institutional, legal, and political. We show that corporate investor preferences for destinations near home remain significant.

We measure distance not only in terms of physical distance, but also in terms of institutional and cultural proximity that could be represented by the physical distance used in gravity models in the FDI literature. Institutional proximity is an important indicator for business climate familiarity. Direct investors prefer to invest in countries with similar economic and legal systems to their own. Cultural distances are also important indicators of investment choices. A commonly spoken language between the host and source countries, a shared history, and organizational culture determine FDI decisions, as they give a competitive advantage to the foreign investor relative to its international competitors. We control for other factors and show that bilateral trust and bilateral tax treaties increase FDI flows, while asymmetric information and bad corporate governance reduce them. The effect of physical distance on FDI location choices remains important. Stulz (2005) argues that one of the reasons for this persistence of home bias and the limited effect of globalization is the twin agency problem: that managers of corporations sometimes act in their own best interests, and 
that governments sometimes limit capital mobility to protect their interests. This is consistent with our findings of persistent home bias in FDI flows. As discussed earlier, managers suffer from various biases or simply do not have the time and resources to look at all investment options, corporate managers being no exception.

Our results are important from a policy perspective. We show that economic activity and country openness are not necessarily the only prerequisites to attract foreign investors. FDIs tend to have a beneficial impact on economic growth, and many countries want to attract them. We show that FDI investors prefer destinations familiar to them. There is need for caution here. Being neighbours or having a shared language may not be the only prerequisites to attract foreign direct investments. Developing the legal frameworks, and improving economic relations and corporate governance will also make the business environment more familiar to foreign direct investors. As such, our results suggest a further research agenda.

This study does not consider the profitability of the investments made in the FDI receiving country, which is a limitation. We use aggregate FDI data, and testing for profitability would be a good extension of a future study using firm-level data, or data on mergers and acquisitions. Firm level work would provide more insight into the reasons for home bias, and whether it could be explained by greater risk and poor performance in certain countries abroad. A further study should consider foreign portfolio investments and how they interact with the movements of FDI flows. Foreign portfolio investors have a different investment motivation from direct investors; however, they play an important role in the target country's investment attraction. Yet another area of future research is to investigate in detail what host countries can do to make their institutional environments more welcoming to foreign investors. 


\section{References:}

Agarwal, J.P., Gubitz, A., Nunnenkamp, P. (1991) Foreign Direct Investment in Developing Countries: The Case of Germany. Tübingen: Mohr Siebeck

Aharoni, Y. (1966) The Foreign Investment Decision Process. Cambridge, MA: Harvard University Press

Ahearne, A.G. Griever, W.L. Warnock, F.E. (2004) "Information costs and home bias: an analysis of US holdings of foreign equities", Journal of International Economics, 62(2), pp. 313-336

Aitken, B.J., Harrison, A. (1999) "Do domestic firms benefit from direct foreign investment? Evidence from Venezuela", American Economic Review, 89(3) pp.605-618

Alcácer, J. (2006) "Location Choices across the Value Chain: How Activity and Capability Influence Collocation”, Management Science 52 (10), pp.1457-1471

Anderson, J.E. (1979) “A Theoretical Foundation for the Gravity Equation”, American Economic Review 69 (1), pp.106-116

Anderson, J. E., van Wincoop, E. (2003) "Gravity with gravitas: a solution to the Border Puzzle”, American Economic Review 93(1), pp.170-192

Barba Navaretti, G., Venables, A.J. (2004) "Multinational Firms in the World Economy", Woodstock, Oxfordshire: Princeton University Press

Bekaert, G. (1995) "Market Integration and Investment Barriers in Emerging Equity Markets", World Bank Economic Review, 9(1), pp.75-107

Bekaert, G., Harvey, C.R., Lundblad, C. (2005) "Does financial liberalization spur growth?" Journal of Financial Economics, 77(1), pp.3-55

Bénassy-Quéré, A., Coupet, M., Mayer, T. (2007) "Institutional Determinants of Foreign Direct Investment", The World Economy, 30(5), pp.764-782

Benito, G.R., Gripsurd, G. (1992) "The Expansion of Foreign Direct Investments: Discrete Rational Location Choices or a Cultural Learning Process?" Journal of International Business Studies, 23(3), pp.461-476

Bergstrand, J.H. (1985) "The Gravity Equation in International Trade: Some Microeconomic Foundations and Empirical Evidence", Review of Economics and Statistics, 67(3), pp. 474481

Bergstrand, J.H., Egger, P. (2007) "A Knowledge-and-Physical-Capital Model of International Trade Flows, Foreign Direct Investment and Multinational Enterprises", Journal of International Economics, 73(2), pp.278-308 
Blonigen, B.A. (2005) “A Review of the Empirical Literature on FDI Determinants", Atlantic Economic Journal, 33(4), pp.383-403

Brainard, L.S. (1997) “An Empirical Assessment of the Proximity-Concentration Trade-off between Multinational Sales and Trade", The American Economic Review, 87(4) pp.520-544 Caves, R.E. (1974) "Causes of Direct Investment: Foreign Firms' Shares in Canadian and United States Manufacturing Industries", Review of Economics and Statistics, 56(3), pp. 279-372

Chakrabarti, A. (2001) "The Determinants of Foreign Direct Investment: Sensitivity Analyses of Cross-Country Regressions", Kyklos, 54(1), pp.89-114

Chan, K., Covrig, V., Ng, L. (2005) "What Determines the Domestic Bias and Foreign Bias? Evidence from Mutual Fund Equity Allocations Worldwide," Journal of Finance, 60(3), pp. $1495-1534$

Coval, J.D., Moskowitz, T.J. (1999) "Home Bias at Home: Local Equity Preference in Domestic Portfolios", Journal of Finance, 54(6), pp.2045-2073

Cumming, D., Dai, N. (2010) "Local bias in venture capital investments", Journal of Empirical Finance, 17(3), pp.362-380

Cyert, R.M., March, J.G. (1963) A Behavioral Theory of the Firm. Englewood Cliffs, NJ: Prentice Hall

Di Giovanni, J. (2005) "What Drives Capital Flows? The case of cross-border M\&A activity and financial deepening", Journal of International Economics, 65(1) pp.127-149

Disdier, A-C., Head, K. (2008) "The Puzzling Persistence of the Distance Effect on Bilateral Trade", The Review of Economics and Statistics, 90(1), pp.37-48

Dongmin, K., Ng, L.K., Wang, Q. (2009) “Home Bias in Foreign Investment Decisions", Journal of International Business Studies, 41(6), pp.960-979

Dow, D., Karunaratna, A. (2006) "Developing a Multidimensional Instrument to Measure Psychic Distance Stimuli”, Journal of International Business Studies, 37(5), pp.578-602

Dunning, J.H. (1980), “Toward an eclectic theory of international production: some empirical tests", Journal of International Business Studies, 11(1), pp.9-31

Egger, P. (2000) “A Note on the Proper Econometric Specification of the Gravity Equation”, Economic Letters, 66(1), pp.25-31

Feenstra, R.C., Markusen, J.R., Rose, A.K., (2001) "Using the Gravity Equation to Differentiate among Alternative Theories of Trade", Canadian Journal of Economics/Revue canadienne d'Economique, 34(2), pp.430-447 
French, K., Poterba, J. (1991) "Investor diversification and international equity markets" American Economic Review, 81(2), pp.222-226

Froot, K.A., Stein, J.C. (1991) "Exchange Rates and Foreign Direct Investment: An Imperfect Capital Market Approach", The Quarterly Journal of Economics, 106(4), pp.11911217

Gordon, R.H., Bovenberg, A.L. (1996) "Why Is Capital so Immobile Internationally? Possible Explanations and Implications for Capital Income Taxation", American Economic Review, 86(5), pp.1057-1075

Graham, J., Harvey, C., Huang, H. (2009) "Investor Competence, Trading Frequency, and Home Bias", Management Science, 55(7) pp.1094-1106

Green, R.T, Cunningham, W.H (1975) “The Determinants of US Foreign Direct Investment: An Empirical Investigation”, Management International Review, 15 (2/3) pp.113-120

Grosse, R., Trevino, L.J. (1996) "Foreign Direct Investment in the United States: An Analysis of Country of Origin", Journal of International Business Studies, 27(1), pp.139-155 Guiso, L., Sapienza, P., Zingales, L. (2009) "Cultural Biases in Economic Exchange?" The Quarterly Journal of Economics, 124(3), pp.1095-1131

Habib, M.; Zurawicki, L. (2002) “Corruption and Foreign Direct Investment" Journal of International Business Studies, 33(2), pp. 291-307

Hattari, R., Rajan, R.S. (2009) "Understanding Bilateral FDI Flows in Developing Asia", Asian-Pacific Economic Literature, 23(2), pp.73-93

Hofstede, G. (1980) Culture's Consequences, International Differences in Work-Related Values (Cross Cultural Research and Methodology). Newbury Park, CA: Sage

Head, K., Meyer, T. (2002) "Illusory Border Effects: Distance Measurement inflates estimates of home bias in trade", CEPII Working Paper, No.2002-01

Head, K., Ries, J. (2008) "FDI as an Outcome of the Market for Corporate Control:Theory and Evidence", Journal of International Economics, 74(1), pp.2-20

Huber, P.J. (1967) “The Behavior of Maximum Likelihood Estimates under Nonstandard Conditions", Proceedings of the Fifth Symposium on Mathematical Statistics and Probability, Vol. I, pp.221-33

Huberman, G. (2001) "Familiarity Breeds Investment", Review of Financial Studies, 14(3), pp.659-80

Johanson, J., Vahlne, J.E. (1977) “The Internationalization Process of the Firm-A Model of Knowledge Development and Increasing Foreign Commitments", Journal of International Business Studies, 8(1), pp.23-32 
Johanson, J., Wiedersheim-Paul, F. (1975) "The Internationalization of the Firm: Four Swedish Cases", Journal of Management Studies, 12(3), pp.305-322

Kang, J.-K., Stulz, R. (1997) "Why is there a home bias? An analysis of foreign portfolio equity ownership in Japan”, Journal of Financial Economics, 46(1), pp.3-28

Kaufmann, D., Kraay, A., Mastruzzi, M. (2009) “Governance Matters VIII: Aggregate and Individual Governance Indicators, 1996-2008”, World Bank Policy Research Working Paper, No.4978

Kindleberger, C.P. (1969) American Business Abroad: Six Lectures on Direct Investment.

New Haven, Conn: Yale University Press

Kleinert, J., Toubal, F. (2010) “Gravity for FDI”, Review of International Economics, 18(1), pp.1-13

Knickerbocker, F.T. (1973) Oligopolistic Reaction and Multinational Enterprise.

Cambridge, MA: Harvard University Press

Kogut, B., Singh, H. (1998) "The Effect of Cultural Distance on the Choice of Entry Mode", Journal of International Business Studies, 19(3) pp.411-432

Kose, J., Freund, S., Nguyen, D., Vasudevan, G.K. (2010) "Investor protection and crossborder acquisitions of private and public targets", Journal of Corporate Finance, 16(3), pp. $259-275$

La Porta, R., Lopez-de-Silanes, F. Shleifer, A., Vishny, R.W. (1998) "Law and Finance", Journal of Political Economy, 106(6), pp.1113-1155

Levine, R. (2001) "International Financial Liberalization and Economic Growth", Review of International Economics, 9(4), pp.688-702

Lewis, K. (1999) “Trying to Explain Home Bias in Equities and Consumption", Journal of Economic Literature, 37(2), pp.571-608

Lim, E.-G. (2001) "Determinants of, and the Relation Between, Foreign Direct Investment and Growth: A Summary of Recent Literature”, IMF Working Papers, 01/175

McCallum, J. (1995) "National Borders Matter: Canada-U.S. Regional Trade Patterns", American Economic Review, 85(3), pp.615-623

Nachum, L., Zaheer, S., Gross, S. (2008) "Does It Matter Where Countries Are? Proximity to Knowledge, Markets and Resources, and MNE Location Choices", Management Science, 54(7), pp.1252-1265

Naseem, A.R., Wei, P.P. (2012) “The performance of frequent acquirers: Evidence from emerging markets", Global Finance Journal, 23(1), pp.16-33 
OECD (Organisation for Economic Co-operation and Development) (2008) Benchmark Definition of Foreign Direct Investment, $4^{\text {th }}$ ed. OECD

Portes, R., Rey, H. (2005) "The determinants of cross-border equity flows", Journal of International Economics, 65(2), pp.269-296

Santos Silva, J.M.C., Tenreyro, S. (2006) "The Log of Gravity", The Review of Economics and Statistics, 88(4), pp.641-658

Santos Silva, J.M.C., Tenreyro, S. (2011), "On the existence of the maximum likelihood estimates in Poisson regression", Economics Letters, 107(2), pp.310-312

Sethi, D., Guisinger, S.E., Phelan, S.E., Berg, D.M. (2003) "Trends in Foreign Direct Investment Flows: A Theoretical and Empirical Analysis", Journal of International Business Studies, 34(4), pp.315-326

Siegel, J.I., Licht, A.N., Schwartz, S.H. (2013) "Egalitarianism, Cultural Distance, and FDI: A New Approach", Organization Science, 24(4), pp.1174-1194

Stulz, R M. (2005) "The Limits of Financial Globalization", Journal of Finance, 60(4), pp. $1595-1638$

Tesar, L., Werner, I. (1995) "Home Bias and High Turnover", Journal of International Money and Finance, 14(4) pp.467-492

Tinbergen, J. (1962) Shaping the World Economy; Suggestions for an International Economic Policy, (Appendix VI). New York: The Twentieth Century Fund

Van Nieuwerburgh, S., Veldkamp, L. (2009) "Information immobility and the Home Bias", Journal of Finance, 64(3), pp.1187-1215

West, J., Graham, J.L. (2004) "A linguistic-based measure of cultural distance and its relationship to managerial values”, Management International Review, 44(3) pp.239-260

White, H. (1980) “A Heteroskedasticity-Consistent Covariance Matrix Estimator and a Direct Test for Heteroskedasticity”, Econometrica, 48(4), pp.817-838

Wheeler, D., Mody, A. (1992) "International Investment Location Decisions: The Case of U.S. Firms", Journal of International Economics, 33(1-2), pp.57-76

Wolf, H. (2000) "International Home Bias in Trade", The Review of Economics and Statistics, 82(4), pp.555-563

$\mathrm{Xu}$, D., Shenkar, O. (2002) "Institutional Distance and the Multinational Enterprise", Academy of Management Review, 27(4), pp. 608-618

Yeyati, E.L., Williams, T. (2011) "Financial Globalization in Emerging Economies: Much Ado About Nothing?” World Bank Policy Research Working Paper Series, No.5624 


\footnotetext{
${ }^{1}$ Also see for home bias in equity markets: Huberman (2001), Kang and Stulz (1997), Coval and Moskowitz (1999), Chan et al. (2005); in mutual fund managers, Dongmin et al. (2009); in venture capital, Cumming and Dai (2010); and personal consumption, Lewis (1999).

${ }^{2}$ We make an alternative panel estimation using positive FDI outflows with OLS and additionally, a static GMM (IV) estimation method (with the first lag of all continuous variables from the main regression used as instruments). Conclusions do not change. Results are available from the authors on request.

${ }^{3}$ OECD member countries: Australia, Austria, Belgium, Canada, Chile, Czech Republic, Denmark, Estonia, Finland, France, Germany, Greece, Hungary, Iceland, Ireland, Israel, Italy, Japan, Korea, Luxembourg, Mexico, Netherlands, New Zealand, Norway, Poland, Portugal, Slovak Republic, Slovenia, Spain, Sweden, Switzerland, Turkey, United Kingdom, United States of America (34 countries).

${ }^{4}$ [Centre D'Etudes Prospectives Et D'Informations Internationales (CEPII)] The distance is measured following Head and Meyer (2002) and the formula for the distances is not a simple air distance between two cities, but it is calculated using the countries' area and the capitals' longitude and latitude: $\left[\mathrm{d}_{\mathrm{i}, \mathrm{j}}=0.67 * \operatorname{sqr}(\operatorname{area} / \pi)\right]$.

5 The same continent dummy variable and the physical distance variable exhibit high correlation of -0.77 . This kind of correlation is to be expected for such variables since they report similar information. The full correlation matrix has been omitted for brevity and is available from the authors on request.

${ }^{6}$ The data for Hofstede's cultural dimensions can be obtained from: www.geert-hofstede.com/

${ }^{7}$ These countries are: Austria, Belgium, the UK, Denmark, the Netherlands, Finland, France, Germany, Greece, Ireland, Italy, Norway, Portugal, Spain and Sweden;

${ }^{8}$ www.itu.int

${ }^{9}$ UNCTAD: United Nations Conference on Trade and Development (www.unctad.org).

10
} 


\section{Table 1. Descriptive Statistics for FDI Outflows}

This table reports the main descriptive statistics of the main and additional variables used in the estimations. These variables are in their original units and also include zero FDI outflows between the country pairs.

\begin{tabular}{|c|c|c|c|c|c|c|c|c|c|c|c|c|c|}
\hline & $\begin{array}{c}\text { FDI } \\
\text { Outflows } \\
\text { (mil\$) }\end{array}$ & $\begin{array}{c}\text { GDP of FDI } \\
\text { Receiving } \\
\text { country(mil\$) }\end{array}$ & $\begin{array}{l}\text { GDP of FDI } \\
\text { Sending } \\
\text { country(mil\$) }\end{array}$ & $\begin{array}{c}\text { Trade } \\
\text { Openness } \\
\text { of the } \\
\text { FDI Rec. } \\
\text { country } \\
(\%) \\
\end{array}$ & $\begin{array}{l}\text { Trade Openness } \\
\text { of the FDI Send. } \\
\text { Country (\%) }\end{array}$ & $\begin{array}{l}\text { Physical } \\
\text { Distance } \\
(\mathbf{k m})\end{array}$ & $\begin{array}{c}\text { Location on } \\
\text { Same } \\
\text { continent }\end{array}$ & $\begin{array}{l}\text { Shared } \\
\text { Border }\end{array}$ & $\begin{array}{c}\text { Econ. } \\
\text { or } \\
\text { Political } \\
\text { Union }\end{array}$ & $\begin{array}{l}\text { Legal Syst. } \\
\text { Origin }\end{array}$ & $\begin{array}{l}\text { Shared } \\
\text { History }\end{array}$ & $\begin{array}{l}\text { Common } \\
\text { Language }\end{array}$ & $\begin{array}{c}\text { Cultural } \\
\text { Distance } \\
\text { Index }\end{array}$ \\
\hline Mean & 339.55 & $361,352.90$ & $1,239,947.47$ & 0.84 & 1.19 & $6,711.53$ & 0.25 & 0.03 & 0.26 & 0.25 & 0.14 & 0.12 & 2.18 \\
\hline Median & 0.00 & $31,121.34$ & $386,504.11$ & 0.72 & 0.47 & $6,510.32$ & 0.00 & 0.00 & 0.00 & 0.00 & 0.00 & 0.00 & 1.99 \\
\hline Maximum & $172,210.10$ & $13,144,400.00$ & $13,144,400.00$ & 4.73 & 150.26 & $19,629.50$ & 1.00 & 1.00 & 1.00 & 1.00 & 1.00 & 1.00 & 10.69 \\
\hline Minimum & 0.00 & 63.62 & $8,789.11$ & 0.05 & 0.05 & 19.13 & 0.00 & 0.00 & 0.00 & 0.00 & 0.00 & 0.00 & 0.02 \\
\hline St. Dev. & $2,365.30$ & $1,220,300.89$ & $2,260,555.57$ & 0.57 & 4.41 & $4,418.10$ & 0.43 & 0.16 & 0.44 & 0.43 & 0.35 & 0.32 & 1.56 \\
\hline \multirow[t]{2}{*}{ Observations } & 50,268 & 61,184 & 66,399 & 50,069 & 50,268 & 65,620 & 66,465 & 65,620 & 66,465 & 63,647 & 65,620 & 65,620 & 28,387 \\
\hline & $\begin{array}{c}\text { Bilateral } \\
\text { Trust }\end{array}$ & $\begin{array}{c}\text { International } \\
\text { Phone Minutes } \\
\text { for rec. Country } \\
\text { per capita } \\
\end{array}$ & $\begin{array}{l}\text { FT circulation } \\
\text { per capita for } \\
\text { rec. country }\end{array}$ & $\begin{array}{c}\text { Bilateral } \\
\text { treaties }\end{array}$ & $\begin{array}{c}\text { Voice and } \\
\text { Accountability }\end{array}$ & $\begin{array}{l}\text { Political } \\
\text { Stability }\end{array}$ & $\begin{array}{l}\text { Government } \\
\text { Effectiveness }\end{array}$ & $\begin{array}{l}\text { Regulatory } \\
\text { Quality }\end{array}$ & $\begin{array}{l}\text { Rule of } \\
\text { Law }\end{array}$ & $\begin{array}{c}\text { Control of } \\
\text { Corruption }\end{array}$ & & & \\
\hline Mean & 2.83 & 8.17 & 0.00 & 0.41 & 0.02 & -0.02 & 0.09 & 0.08 & 0.03 & 0.06 & & & \\
\hline Median & 2.78 & 8.19 & 0.00 & 0.00 & 0.04 & 0.10 & -0.09 & -0.05 & -0.14 & -0.21 & & & \\
\hline Maximum & 3.69 & 10.85 & 0.01 & 1.00 & 1.83 & 1.67 & 2.37 & 2.23 & 2.01 & 2.60 & & & \\
\hline Minimum & 2.18 & 4.40 & 0.00 & 0.00 & -2.30 & -3.30 & -2.45 & -2.66 & -2.68 & -1.92 & & & \\
\hline St. Dev. & 0.32 & 0.91 & 0.00 & 0.49 & 1.01 & 0.98 & 1.03 & 1.02 & 1.02 & 1.05 & & & \\
\hline Observations & 4,105 & 42,854 & 28,716 & 60,543 & 47,756 & 47,633 & 47,493 & 47,495 & 47,698 & 47,493 & & & \\
\hline
\end{tabular}




\section{Table2. Home Bias in FDI Outflows}

Dependant variable is $\log$ (FDI outflows ${ }_{i, j, t}$ ) which represents foreign direct investment flow from country $i$ to country $j$ at time $t$; The FDI outflows are from the FDI sending country towards the FDI receiving country. The explanatory variables are: Log of the GDP of the FDI receiving country; log of the GDP for the FDI sending country; trade openness (ratio of exports plus imports over GDP) for the FDI receiving country; trade openness (ratio of exports plus imports over GDP) for the FDI sending country; the log of the physical distance between the country $i$ and $j$ in kilometres; shared continent dummy (value of one if the two countries i and $j$ are on the same continent); shared border dummy (value of one if country $i$ and $j$ share a border); shared economic or political union dummy (value of one if country $i$ and $j$ share membership in the same economic or political union); same legal origin dummy (one if country $i$ and $j$ share the same origin of their legal systems); shared language (one if country $i$ and $j$ share the same official language or language of the minorities); shared history (one if country $i$ and $j$ share history with respect to having had a past colonial relationship or having been part of the same country). Robust standard errors (Huber/White); Time fixed effects applied; Note that $* * *, * * *$ stand for significant coefficients at the $10 \%, 5 \%$ and $1 \%$ level, respectively.

\begin{tabular}{|c|c|c|c|c|c|c|c|c|c|}
\hline & $\begin{array}{c}\text { (1) } \\
\text { FDI Outflows }\end{array}$ & $\begin{array}{c}\text { (2) } \\
\text { FDI Outflows }\end{array}$ & $\begin{array}{c}\text { (3) } \\
\text { FDI Outflows }\end{array}$ & $\begin{array}{c}\text { (4) } \\
\text { FDI Outflows }\end{array}$ & $\begin{array}{c}\text { (5) } \\
\text { FDI Outflows }\end{array}$ & $\begin{array}{c}\text { (6) } \\
\text { FDI Outflows }\end{array}$ & $\begin{array}{c}(7) \\
\text { FDI Outflows }\end{array}$ & $\begin{array}{c}\text { (8) } \\
\text { FDI Outflows }\end{array}$ & $\begin{array}{c}\text { (9) } \\
\text { FDI Outflows }\end{array}$ \\
\hline $\mathbf{C}$ & $-7.67 * * *$ & $-17.88 * * *$ & $-17.56^{* * *}$ & $-17.52 * * *$ & $-17.63 * * *$ & $-17.82 * * *$ & $-18.10 * * *$ & $-17.47 * * *$ & $-14.85^{* * *}$ \\
\hline (Log) GDPrec & $1.53 * * *$ & $1.94 * * *$ & $1.93 * * *$ & $1.94 * * *$ & $1.77 * * *$ & $1.76^{* * *}$ & $1.76^{* * *}$ & $1.75 * * *$ & $1.73 * * *$ \\
\hline (Log) GDP send & $1.40 * * *$ & $2.45 * * *$ & $2.44 * * *$ & $2.45 * * *$ & $2.39 * * *$ & $2.38 * * *$ & $2.36 * * *$ & $2.32 * * *$ & $2.32 * * *$ \\
\hline Openness rec & & $0.75 * * *$ & $0.75 * * *$ & $0.75 * * *$ & $0.85 * * *$ & $0.83 * * *$ & $0.81 * * *$ & $0.79 * * *$ & $0.81 * * *$ \\
\hline Openness send & & $1.77 * * *$ & $1.75 * * *$ & $1.76 * * *$ & $1.74 * * *$ & $1.73 * * *$ & $1.73 * * *$ & $1.69 * * *$ & $1.61 * * *$ \\
\hline (Log) Distance & $-1.25 * * *$ & $-1.05 * * *$ & $-1.10 * * *$ & $-1.13^{* * *}$ & $-0.92 * * *$ & $-0.86^{* * *}$ & $-0.77 * * *$ & $-0.84 * * *$ & $-1.40 * * *$ \\
\hline Same Continent & & & -0.08 & -0.07 & $-0.15^{* *}$ & -0.12 & 0.08 & $-0.11^{*}$ & $-0.28 * * *$ \\
\hline Border & & & & -0.05 & -0.02 & -0.08 & -0.09 & $-0.37 * * *$ & $-0.75 * * *$ \\
\hline Shared Econ. Org. & & & & & $0.97 * * *$ & $0.97 * * *$ & $0.86^{* * *}$ & $0.86^{* * *}$ & $0.68 * * *$ \\
\hline $\begin{array}{c}\text { Same Legal } \\
\text { System }\end{array}$ & & & & & & $0.36^{* * *}$ & $0.21 * * *$ & $0.09 *$ & $0.23 * * *$ \\
\hline Shared History & & & & & & & $0.67 * * *$ & $0.52 * * *$ & $0.37 * * *$ \\
\hline Shared Language & & & & & & & & $0.50 * * *$ & $0.38 * * *$ \\
\hline Cul. Dist. Ind. & & & & & & & & & $-0.13 * * *$ \\
\hline $\mathbf{N}$ & 45,782 & 37,455 & 37,455 & 37,455 & 37,455 & 37,433 & 37,433 & 37,433 & 20,249 \\
\hline
\end{tabular}




\section{Table 3. Home Bias in FDI Outflows Across Time;}

Dependant variable is FDI outflows ${ }_{i, j, t}$ which represents foreign direct investment flow from country $i$ to country $\mathrm{j}$ at time $\mathrm{t}$; the time is split in two sub-periods: 1981-1995 (2) and 1996-2010 (3). The sub-periods are formed based on discussions in Bekaert (1995) and Bekaert et al. (2005). The FDI outflows are from the FDI sending country towards the FDI receiving country. The explanatory variables are: Log of the GDP of the FDI receiving country; log of the GDP for the FDI sending country; trade openness (ratio of exports plus imports over GDP) for the FDI receiving country; trade openness (ratio of exports plus imports over GDP) for the FDI sending country; the log of the physical distance between the country $i$ and $j$ in kilometres; shared continent dummy (value of one if the two countries $i$ and $j$ are one the same continent); shared border dummy (value of one if country $i$ and $j$ share a border); shared economic or political union dummy (value of one if country $i$ and $j$ share membership in the same economic or political union); same legal origin dummy (one if country $i$ and $j$ share the same origin of their legal systems); shared language (one if country $i$ and $j$ share the same official language or language of the minorities); shared history (one if country $i$ and $j$ share history with respect to having had a past colonial relationship or having been part of the same country); cultural distance index (based on Kogut and Singh (1988)); Robust standard errors (Huber/White); Time fixed effects applied; Note that $*, * *, * * *$ stand for significant coefficients at the $10 \%, 5 \%$ and $1 \%$ level, respectively.

\begin{tabular}{|cc|c|c|}
\hline & $\mathbf{( 1 )}$ & $\mathbf{( 2 )}$ & $\mathbf{( 3 )}$ \\
\hline $\mathbf{C}$ & FDI Outflows & FDI Outflows 1981-1995 & FDI Outflows 1996-2010 \\
\hline (Log) GDPrec & $-14.85^{* * *}$ & $-22.48^{* * *}$ & $-13.50^{* * *}$ \\
(Log) GDP send & $1.73^{* * *}$ & $2.11^{* * *}$ & $1.71^{* * *}$ \\
Openness rec & $2.32^{* * *}$ & $2.37^{* * *}$ & $2.28^{* * *}$ \\
Openness send & $0.81^{* * *}$ & $0.99^{* * *}$ & $0.81^{* * *}$ \\
(Log) Distance & $1.61^{* * *}$ & $1.05^{* * *}$ & $1.56^{* * *}$ \\
Same Continent & $-1.40^{* * *}$ & -0.10 & $-1.56^{* * *}$ \\
Border & $-0.28^{* * *}$ & $0.70^{* * *}$ & $-0.40^{* * *}$ \\
Shared Econ. Org. & $-0.75^{* * *}$ & $-0.31^{* * *}$ & $-0.81^{* * *}$ \\
Same Legal System & $0.68^{* * *}$ & $0.68^{* * *}$ & $0.70^{* * *}$ \\
Shared History & $0.23^{* * *}$ & 0.08 & $0.25^{* * *}$ \\
Shared Language & $0.37^{* * *}$ & $0.24^{* * *}$ & $0.36^{* * *}$ \\
Cul. Dist. Index & $0.38^{* * *}$ & $0.47^{* * *}$ & $0.37^{* * *}$ \\
\hline & $-0.13^{* * *}$ & 0.02 & $-0.16^{* * *}$ \\
\hline N & & & \\
& $\mathbf{2 0 , 2 4 9}$ & $\mathbf{5 , 6 7 6}$ & $\mathbf{1 4 , 5 7 3}$ \\
\hline
\end{tabular}




\section{Table 4. Home Bias in FDI Outflows and Trust, Asymmetric Information and Bilateral Tax Treaties}

Dependant variable is FDI outflows $\mathrm{i}_{\mathrm{i}, \mathrm{j}, \mathrm{t}}$ which represents foreign direct investment flow from country $\mathrm{i}$ to country $\mathrm{j}$ at time $\mathrm{t}$; The FDI outflows are from the FDI sending country towards the FDI receiving country. The explanatory variables are: Log of the GDP of the FDI receiving country; log of the GDP for the FDI sending country; trade openness (ratio of exports plus imports over GDP) for the FDI receiving country; trade openness (ratio of exports plus imports over GDP) for the FDI sending country; the log of the physical distance between the country $i$ and $j$ in kilometres; shared continent dummy (value of one if the two countries $i$ and $j$ are one the same continent); shared border dummy (value of one if country $i$ and $j$ share a border); shared economic or political union dummy (value of one if country $i$ and $j$ share membership in the same economic or political union); same legal origin dummy (one if country $i$ and $j$ share the same origin of their legal systems); shared language (one if country $i$ and $j$ share the same official language or language of the minorities); shared history (one if country $\mathrm{i}$ and $\mathrm{j}$ share history with respect to having had a past colonial relationship or having been part of the same country); cultural distance index (based on Kogut and Singh, (1988)); bilateral trust between the citizens of two countries (from Guiso et al. (2009)); international telephone calls in minutes per capita for the FDI receiving country; financial times circulation per capita for the FDI outflows receiving country; bilateral tax treaties for double taxation avoidance. Robust standard errors (Huber/White); Time fixed effects applied; Note that $*, * *, * * *$ stand for significant coefficients at the $10 \%, 5 \%$ and $1 \%$ level, respectively.

\begin{tabular}{|c|c|c|c|c|c|}
\hline & $\begin{array}{c}\text { (1) } \\
\text { FDI Outflows }\end{array}$ & $\begin{array}{c}\text { (2) } \\
\text { FDI Outflows }\end{array}$ & $\begin{array}{c}\text { (3) } \\
\text { FDI Outflows }\end{array}$ & $\begin{array}{c}(4) \\
\text { FDI Outflows }\end{array}$ & $\begin{array}{c}\text { (5) } \\
\text { FDI Outflows }\end{array}$ \\
\hline $\mathrm{C}$ & $-14.85 * * *$ & $-11.32 * * *$ & $-15.16^{* * *}$ & $-13.54 * * *$ & $-14.71 * * *$ \\
\hline (Log) GDPrec & $1.73 * * *$ & $1.74 * * *$ & $1.82^{* * *}$ & $1.67^{* * *}$ & $1.74 * * *$ \\
\hline (Log) GDP send & $2.32 * * *$ & $1.76^{* * *}$ & $2.31^{* * *}$ & $2.26 * * *$ & $2.35^{* * *}$ \\
\hline Openness rec & $0.81 * * *$ & $0.85^{* * *}$ & $0.95 * * *$ & $0.66^{* * *}$ & $0.82^{* * *}$ \\
\hline Openness send & $1.61 * * *$ & 0.29 & $1.61 * * *$ & $1.57 * * *$ & $1.55^{* * *}$ \\
\hline (Log) Distance & $-1.40 * * *$ & $-1.80 * * *$ & $-1.31 * * *$ & $-1.41^{* * *}$ & $-1.32 * * *$ \\
\hline Same Continent & $-0.28 * * *$ & N/A & -0.13 & $-0.37 * * *$ & $-0.21 * * *$ \\
\hline Border & $-0.75^{* * *}$ & $-0.60 * * *$ & $-0.75 * * *$ & $-0.60 * * *$ & $-0.75 * * *$ \\
\hline Shared Econ. Org. & $0.68 * * *$ & N/A & $0.58 * * *$ & $0.56^{* * *}$ & $0.68 * * *$ \\
\hline Same Legal System & $0.23^{* * *}$ & $0.39 * * *$ & $0.19 * * *$ & $0.29 * * *$ & $0.23 * * *$ \\
\hline Shared History & $0.37 * * *$ & $0.69 * *$ & $0.36^{* * *}$ & $0.31^{* * *}$ & $0.39^{* * *}$ \\
\hline Shared Language & $0.38 * * *$ & -0.49 & $0.46^{* * *}$ & $0.28 * * *$ & $0.39 * * *$ \\
\hline Cul. Dist. Index & $-0.13 * * *$ & 0.04 & $-0.14 * * *$ & $-0.13 * * *$ & $-0.13 * * *$ \\
\hline Bil. Trust & & $0.83^{* * *}$ & & & \\
\hline L(Int. Phone Calls/capita) & & & -0.02 & & \\
\hline (FT/capita) & & & & $122.37 * * *$ & \\
\hline Bilat. tax treaties & & & & & 0.06 \\
\hline $\mathbf{N}$ & 20,249 & 2,975 & 15,419 & 12,725 & 18,209 \\
\hline
\end{tabular}




\section{Table 5. Country Governance Factors and Home Bias in FDI Outflows;}

Dependant variable is FDI outflows $i, j, t$, which represents foreign direct investment flow from country $i$ to country $j$ at time $t$; the FDI outflows are from the FDI sending country towards the FDI receiving country. The explanatory variables are: Log of the GDP of the FDI receiving country; log of the GDP for the FDI sending country; trade openness (ratio of exports plus imports over GDP) for the FDI receiving country; trade openness (ratio of exports plus imports over GDP) for the FDI sending country; the log of the physical distance between the country $i$ and $j$ in kilometres; shared continent dummy (value of one if the two country $i$ and $j$ are one the same continent); shared border dummy (value of one if country $i$ and $j$ share a border); shared economic or political union dummy (value of one if country $i$ and $j$ share membership in the same economic or political union); same legal origin dummy (one if country $\mathrm{i}$ and $\mathrm{j}$ share the same origin of their legal systems); shared language (one if country $i$ and $j$ share the same official language or language of the minorities); shared history (one if country $\mathrm{i}$ and $\mathrm{j}$ share history with respect to having had a past colonial relationship or having been part of the same country); cultural distance index (based on Kogut and Singh (1988)); voice and accountability index; political stability and absence of violence index; government effectiveness; regulatory quality; rule of law; control of corruption. Robust standard errors (Huber/White); Time fixed effects applied; Note that *, **, *** stand for significant coefficients at the $10 \%, 5 \%$ and $1 \%$ level, respectively.

\begin{tabular}{|c|c|c|c|c|c|c|}
\hline & $\begin{array}{c}\text { (1) } \\
\text { FDI Outflows }\end{array}$ & $\begin{array}{c}\text { (2) } \\
\text { FDI Outflows }\end{array}$ & $\begin{array}{c}\text { (3) } \\
\text { FDI Outflows }\end{array}$ & $\begin{array}{c}\text { (4) } \\
\text { FDI Outflows }\end{array}$ & $\begin{array}{c}\text { (5) } \\
\text { FDI Outflows }\end{array}$ & $\begin{array}{c}\text { (6) } \\
\text { FDI Outflows }\end{array}$ \\
\hline $\begin{array}{c}\text { C } \\
\text { (Log) GDPrec }\end{array}$ & $\begin{array}{c}-13.29 * * * \\
1.65 * * *\end{array}$ & $\begin{array}{c}-12.52 * * * \\
1.65 * * *\end{array}$ & $\begin{array}{c}-12.27 * * * \\
1.55^{* * *}\end{array}$ & $\begin{array}{c}-11.91 * * * \\
1.48^{* * *}\end{array}$ & $\begin{array}{c}-12.28^{* * *} \\
1.55^{* * *}\end{array}$ & $\begin{array}{c}-12.13^{* * *} \\
1.53 * * *\end{array}$ \\
\hline (Log) GDP send & $2.27 * * *$ & $2.26^{* * *}$ & $2.25 * * *$ & $2.25^{* * *}$ & $2.26^{* * *}$ & $2.25^{* * *}$ \\
\hline Openness rec & $0.75 * * *$ & $0.70 * * *$ & $0.65 * * *$ & $0.54 * * *$ & $0.65 * * *$ & $0.60 * * *$ \\
\hline Openness send & $1.56^{* * *}$ & $1.53 * * *$ & $1.54 * * *$ & $1.54 * * *$ & $1.54 * * *$ & $1.53 * * *$ \\
\hline (Log) Distance & $-1.49 * * *$ & $-1.62 * * *$ & $-1.56^{* * *}$ & $-1.56 * * *$ & $-1.56^{* * *}$ & $-1.53 * * *$ \\
\hline Same Continent & $-0.37 * * *$ & $-0.44 * * *$ & $-0.40 * * *$ & $-0.42 * * *$ & $-0.40 * * *$ & $-0.39 * * *$ \\
\hline Border & $-0.80 * * *$ & $-0.86^{* * *}$ & $-0.81 * * *$ & $-0.74 * * *$ & $-0.80 * * *$ & $-0.78 * * *$ \\
\hline Shared Econ. Org. & 0.12 & $0.51 * * *$ & $0.44 * * *$ & $0.25^{* * *}$ & $0.37 * * *$ & $0.35^{* * *}$ \\
\hline Same Legal System & $0.35^{* * *}$ & $0.27 * * *$ & $0.28 * * *$ & $0.30 * * *$ & $0.28 * * *$ & $0.37 * * *$ \\
\hline Shared History & $0.35 * * *$ & $0.36 * * *$ & $0.36^{* * *}$ & $0.35 * * *$ & $0.36^{* * *}$ & $0.28 * * *$ \\
\hline Shared Language & $0.31 * * *$ & $0.36 * * *$ & $0.30 * * *$ & $0.26 * *$ & $0.30 * * *$ & $0.28 * * *$ \\
\hline Cul. Dist. Index & $-0.12 * * *$ & $-0.15 * * *$ & $-0.16^{* * *}$ & $-0.14 * * *$ & $-015 * * *$ & $-0.15^{* * *}$ \\
\hline Voice and Acc. & $0.47 * * *$ & & & & & \\
\hline Polit. Stab. & & $0.19 * * *$ & & & & \\
\hline Gov. Effect. & & & $0.28 * * *$ & & & \\
\hline Regulat. Quality & & & & $0.51 * * *$ & & \\
\hline Rule of Law & & & & & $0.29 * * *$ & \\
\hline Control of Corr. & & & & & & $0.31^{* * *}$ \\
\hline
\end{tabular}

